\title{
Volcher Coiter on the Eye
}

\begin{abstract}
A pupil of Andreas Vesalius, Coiter is little known in ophthalmology even though his original contributions were seminal for the field's further development. They consisted of his discovery of the corrugator supercilii muscle, the fibrous nature of the optic nerve, and above all the regeneration of aqueous humour, which removed Galen's obstructive fear of aqueous loss by accident or by surgery. Eye (2009) 23, 1629-1632; doi:10.1038/eye.2009.135; published online 29 May 2009
\end{abstract}

Keywords: Coiter; aqueous humour; corrugator muscle; optic nerve

The renaissance in medicine is generally said to have begun with Andreas Vesalius' (1514-1564) publication of his De humani corporis fabrica in 1543. As a consequence of his insistence on actual reproducible evidence, based on careful dissections of human bodies, the sixteenth century was flush with new discoveries contradicting Galen's anatomy that was the accepted dogma. One of his contemporaries was Volcher Coiter (1534-1576), whose three main contributions to ophthalmology consisted of his discovery of the corrugator supercilii muscle, the discovery, with Fallopius, that the optic nerve was composed of multiple fibres, and the notation that the aqueous humour replenished itself.

\section{Corrugator muscle}

Describing the muscles of the head, Coiter included for the first time a detailed anatomy of the corrugator supercilii muscle, which The American Encyclopedia and Dictionary of Ophthalmology of 1914 simply listed under 'Coiter's corrugator'.

Firstly there is one on either side beneath the skin of the eyebrow, rather thick where the eyebrows appear to be swollen, but thinner in others; their origin (at which they are broad and thin) lies near the larger corner of the eye, where the

HH Mark

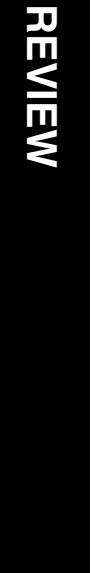

lachrymal ducts are, and from there they ascend on either side to the origin or bridge of the nose. ${ }^{1}$

At the time, the function of this and other muscles could only be inferred from bodily motions, as electricity was unknown, and hence its voltaic application to detect muscle contractions:

The function of these muscles, together with those of the lids, is to completely and thoroughly to close the eyes, when we are either in the water or surrounded by smoke and dust, to avert every injury, and to place a cover resembling a tile before the eyes.

Duke-Elder ${ }^{2}$ noted that its action is accompanied by the formation of vertical furrows in the centre of the lower part of the forehead -

the facial characteristic of a frown'. Eugene Wolff ${ }^{3}$ thought that 'In relation to facial expression it is par excellence the muscle of 'trouble'. As such it recently gained some prominence when facial appearance became important, and with it the elimination of the vertical frown-lines by Botox injections or surgery.

\section{Optic nerve}

The Greek and Roman humoural physiology held that obstruction of the flow of visual spirits through the hollow optic nerves caused blindness. Vesalius doubted the existence of such a channel but did not prove it, this was left to his pupils Gabriel Fallopius and Coiter.

That this is a general rule is apparent in all nerves, not even the optic nerve being excepted. More, I do not believe that there is one nerve which consists of a single thread of fibre, though some of those nerves which united before they penetrate the hard membrane [dura], thus forming a single nerve, do consist of multiple hairlike fibres, taking their respective origins in places far distance from each other (Coiter, ${ }^{1}$ p 113).
Yale-New Haven Hospital, North Haven, CT, USA

Correspondence: HH Mark, Ophthalmology,

Yale-New Haven Hospital, 16 Broadway, North Haven, CT 06473-2301, USA

Tel: + 20323422 12;

Fax: + 2032342212 .

E-mail: iimd@aol.com

Received: 28 April 2009 Accepted: 28 April 2009 Published online: 29 May 2009 


\section{TABVLA OCVLORVM}

HVMANOR VM.

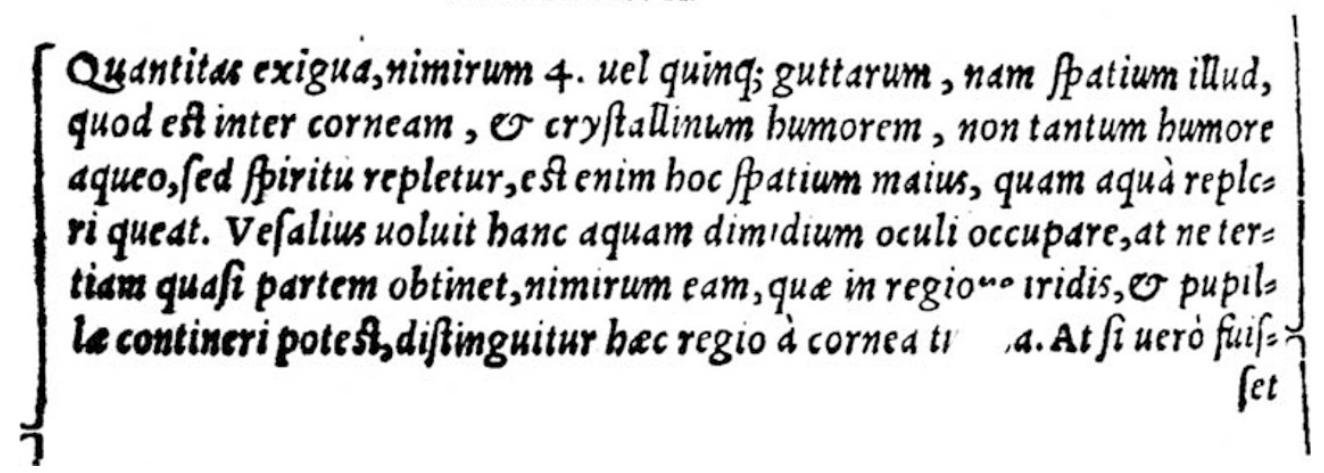

Figure 1 Coiter's title on the eye with the section on aqueous replenishment.

How the visual sensation was carried through these nerve fibres was then left to each author's imagination, but was most often thought to ensue with the help of 'animal spirits', which pervaded the human body. In this connection it is perhaps interesting to note Isaac Newton's often overlooked ${ }^{4}$ dissection and experiments with the optic nerves of a sheep:

Though I tyed a piece of the optic nerve at one end and warmed it in the middle to see if any aery substance by that means would disclose itself in bubbles at the other end, I could not spy the least bubble; a little moisture only and the marrow itself squeezed out. ${ }^{5}$

The mechanism by which stimuli were conducted in these nerves was envisioned by Newton to be by repeated internal reflections, akin to that in fibre-optic cables of today:

Nay granting me but that there are pipes filled with a pure transparent liquor passing from the eye to the sensorium and the vibrating motion of the aether will of necessity run along thither. For nothing interrupts that motion but reflecting surfaces, and therefore also that motion cannot stray through the reflecting surfaces of the pipe but must rush along (like a sound in a trunk) intire to the sensorium. And that vision be thus made is very conformable to the sense of hearing which is made by like vibrations.

\section{Aqueous humour}

Coiter's chapter on the eye stands out because the structure and function of the eye and ear did not usually deserve a separate section in sixteenth century textbooks of anatomy. It was 15 large pages long, in the form of a table titled Tabula oculorum humanorum. ${ }^{6}$ This diagrammatic form was useful (Coiter said he had seen it used in Bologna and Perugia) most likely because of its economy as a teaching device, for printing and books were expensive. Leonhart Fuchs, ${ }^{7}$ who probably taught Coiter, and whose textbooks were standard at the time, printed a similar table in 1538, although it dealt mostly with diseases of the eyes rather than its anatomy. Neither table has yet been translated from the Latin.

The monograph contained much original work, including details on the lacrimal gland and the muscles of the lids. Of particular interest today is his section on the anatomy and physiology of the aqueous humour, for, though brief, it was here that for the first time the continuous replenishment of the aqueous was published. 8 '...non tantum humore aqueo, sed spiritu repletur, est enim hoc spatium maius, quam aqua repleri queat' (Figure 1).

Galen and Celsus taught that the aqueous was nourishing the lens, the actual organ of vision; any loss of aqueous damaged the lens and caused blindness. Removal of this belief was hence the first step on the road towards extraction of the cataractous lens, with its inadvertent loss of aqueous, or towards drainage of aqueous for other therapeutic ends. A decade after Coiter the famous Jacques Guillemeau (1550-1613) wrote on the subject in his book of 1585 (translated in due course into English by three different authors, including Richard Banister and Sir William Read):

... albeit that some will constantly aduouch the aforesaid humours may be engendered again. For proof of their speach they bring the trial which has been made on a pigeons eyes, whereof they crushed forth the humours which nevertheless in 15 days they have found recovered, and the eyes as plain and sound as before, which I am able to 


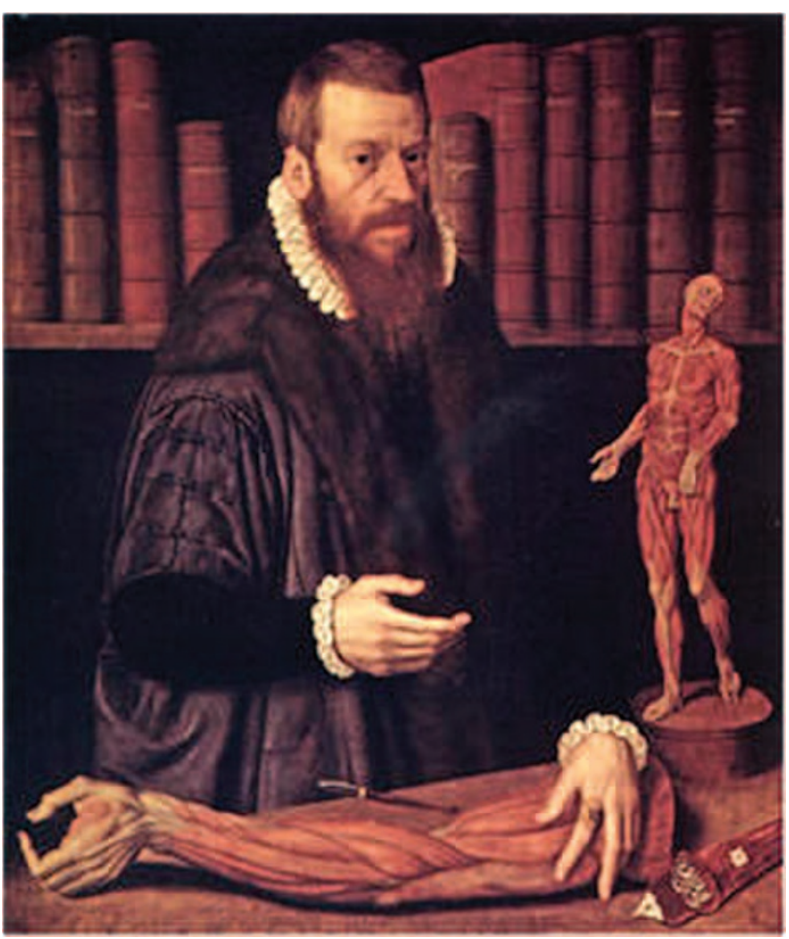

Figure 2 Volcher Coiter, courtesy of the municipal museum of Nürnberg.

testify that I have seen, but it has not been produced true in any man. ${ }^{9}$

A little loss of aqueous in man was nevertheless harmless:

For my part I have seen much of the waterish humour issue forth when the needle has been plucked forth, which was thrust in to take away the cataracts, and afterward in short time the eye has been as full great and fair as at the beginning; which yet could not be if all the humours were lost.

\section{Life of Coiter}

Coiter was born in 1534 to a well to do patrician family in the free Hanseatic city of Groningen in the province of Friesland, soon to be absorbed into the Habsburg monarchy. His ability was such that upon graduation from high school the city awarded him a stipend to study abroad for 5 years. ${ }^{10}$ He took the opportunity to move south, passing through Tübingen, where he probably heard the eminent teacher Leonhart Fuchs. In 1556 he studied in the renowned university of Montpelier, there meeting and befriending Felix Platter (1536-1614), the anatomist who in his book of 1583 insisted that the retina was the actual organ of vision.
The following year Coiter moved to Padua to study under Gabriel Fallopius (1537-1562), whose lectures he later published with his own corrections, additions, and illustrations. ${ }^{11}$ By 1560 he was in Bologna, studying under Ulisse Aldorvandi and Giulio Arenzi, graduating in 1562 with a degree of 'Doctor of Arts and Medicine'. He stayed for a while in Rome to study under Bartolomeo Eustachi (1524-1574), and in 1563 returned to Bologna to teach surgery and dissection. There his first two publications appeared in the form of tables, on the external parts of the human body in 1564 ('with license from the inquisition' $)^{12}$ and 16 pages on the bones and cartilages in $1566 .{ }^{13}$

One night in late winter of 1565 , being a pious protestant, Coiter was dragged out of bed and brought in chains to Rome where he spent a few months in jail, continued thereafter in Bologna. He was released with the help of German countrymen and moved to the small town of Amberg east of Nürnberg. Three years later he moved to the larger town of Nürnberg where he published his main works: the external and internal principal parts of the human body ${ }^{14}$ in 1572 and 1573, and the lectures of Gabriel Fallopi in $1575 .{ }^{6}$ He also issued a couple of pamphlets on how to properly use the mineral baths, a popular means to maintaining one's health in Germany, then and now. In the fall of 1575, Coiter enlisted as physician in the care of an expeditionary army of some 20000 soldiers assembled by Pfalzgraf Johann Casimir to invade France in support of the Huguenots, his fellow protestants. On the way back he fell ill and died in Champagne in June 1576, leaving his widow saddled with a large debt, monies he borrowed to finance his last book.

Coiter set Vesalius as his role model by emphsizing dissection of the normal and pathological human body, in the layout of his books, and finally in his portrait (Figure 2). The representation of many skeletons of humans, fetuses, children and animals established him as the founder of comparative osteology. In addition, he was credited with epochal early contributions to embryology for his research on the development of the chicken's egg, ${ }^{15}$ the first since Aristotle. ${ }^{16}$ The work on the skeletons of birds earned him a place in ornithology, and the detailed description of the ear secured a prominent position in the history of otology. His name is remembered in balneology for his writings on the baths, and the history of medical illustration for his fine drawings in his books by his own hand. His artistic talents covered music as well, for he played the lute and taught Felix Platter how to play the harp.

\section{Conflict of interest}

The author declares no conflict of interest. 


\section{References}

1 Coiter V. Lectures... on the corresponding parts of the human body. In: Opuscula selecta Neerlandicorum de arte medica, Vol. 18, Sumptibus Societatis: Amsetrdam, 1955, p 117.

2 Duke-Elder S. System of Ophthalmology, 2nd Vol CV Mosby: St Louis, 1961, p 502.

3 Wolff E. Anatomy of the Eye and Orbit. WB Saunders: Philadelphia, 1961, p 179.

4 Reeves C, Taylor D. A history of the optic nerve and its diseases. Eye 2004; 18: 1096-1109.

5 McGuire JE, Tamy M. Certain Philosophical Questions. University Press: Cambridge, 1983, pp 487-488.

6 Coiter V. Lectiones Gabrielis Fallopii. In: Externarum et internarum principalium humani corporis. T Gerlachii: Noribergae, 1573, pp 73-87.

7 Fuchs L. Tabula oculorum morbos comprehendes, 1538. (Facs.), Palo Alto: privately printed, 1949.
8 Hirschberg J. Geschichte der Augenheilkunde. In: GraefeSaemisch Handbuch der Gesamten Augenheilkunde, Vol. 14, W Engelmann: Leipzig, 1911, pp 259-260.

9 Guillemeau J. A worthy treatise of the eyes, (Anthony Hunton transl.) R Waldegrave: London, 1587, p 19.

10 Schullian DM. Coiter, Volcher. In: Dictionary of scientific biography, 3rd Vol C Scribner: New York, 1971, pp 342-343.

11 Herrlinger R. Volcher Coiter. Edelman: Nürnberg, 1952, pp 91-93.

12 Coiter V. Tabulae externarum partium humani corporis. A Benaccium: Bononiae, 1564.

13 Coiter V. De ossibus et cartilaginibus humani corporis. I Rossium: Bononiae, 1566.

14 Coiter V. Externarum et internarum principalium humani corporis. T. Gerlatzeni: Noribergae, 1572.

15 Coiter V. The 'De ovorum gallinacorum generationis'. PB Hoeber: New York, 1933.

16 Harré R. Aristotle, the embryology of the chick. In: Great Scientific experiments. University Press: Oxford, 1981, pp 25-32. 